\title{
Does Tax Knowledge Motivate Tax Compliance in Malaysia?
}

\author{
Sahari Salawati ${ }^{1}$, Nivakan Sritharan ${ }^{1}$, Sharon Cheuk Choy Sheung ${ }^{1} \&$ Ahmad Syubaili Mohamed ${ }^{1}$ \\ ${ }^{1}$ Faculty of Economics \& Business, Universiti Malaysia Sarawak, Sarawak, Malaysia \\ Correspondence: Sahari Salawati, Faculty of Economics \& Business, Universiti Malaysia Sarawak, 94300 \\ Samarahan, Sarawak, Malaysia. E-mail: ssalawati@unimas.my
}

Received: October 1, 2020

Accepted: December 2, 2020

Online Published: January 6, 2021

doi:10.5430/rwe.v12n1p238

URL: https://doi.org/10.5430/rwe.v12n1p238

\begin{abstract}
This study aims to clarify whether tax knowledge of individual taxpayers motivates tax compliance in Malaysia. Studies with similar topics express the fact that there still exists a gap in profiling the demographic characteristics of knowledgeable taxpayers and better compliant taxpayers in Malaysia. Age, gender, income groups, and education level were the demographic variables used to study the association. The study applied a survey method for data collection. The population targeted was the individual taxpayers across Malaysia, whereby a sample of 419 respondents involved in this study. T-test, One-Way ANOVA, and Pearson correlation analysis had been employed to analyse the data. The outcome of the study reveals that knowledgeable taxpayers are not better tax complaining of taxpayers in Malaysia. Further, the relationship between tax knowledge and tax compliance is negative and insignificant. This paper studied the association of tax knowledge with tax compliance level, which attempt to contribute to the literature and aids tax administration to intensify not only tax law educations but also tax penalties for tax evaders.
\end{abstract}

Keywords: tax compliance, tax knowledge, demographic factors

\section{Introduction}

Tax non-compliance is a behavior, in which the residents of Malaysia intentionally or unintentionally do not comply with the tax system, violating the Income Tax Act. No. 53, Section 103. The existence of tax non-compliance in Malaysia was identified by the government of Malaysia as well as the Inland Revenue Board of Malaysia who confirms that a tax gap of RM 13 billion is recorded (Ministry of Finance Malaysia, 2019). This issue, tax non-compliance, is critical in Malaysia since forty to sixty percent of national revenue solely depends on income taxes. Reducing the tax gap should require the formation of strategies, which could be possible once the cause for the tax gap is found out. The cause for the tax gap, which is the non-compliance behavior of residents, slows down the government's operational activities since the national revenue is mostly allocated for the operational expenditure than for the developmental expenditure (Refer to Figure 2). The extracts are taken from some of the past research studies, Present news articles, released by the Inland Revenue Board (IRBM) of Malaysia to the public from 2016 to 2019 , reveal that there exists a gap between the total amount of taxes to be collected and the actual amount of taxes collected as tax.

According to the Inland Revenue Board of Malaysia, the tax gap (differences between expected tax collection and actual tax collection) was RM 20.7, RM 1.0, RM 3.4, and RM 13.3 billion for the years 2015, 2016, 2017, and 2018, respectively. The tax authority of Malaysia confronts difficulties in collecting taxes and in executing of tax compliance system (Inland Revenue Board of Malaysia, 2018). During the announcement of the budget for the year 2019, the Minister of Finance launched a special voluntary disclosure program to allow taxpayers who have not yet been complied with the tax system.

Malaysia established its Self-Assessment System (E-filing) for taxation in 2004. The pre-SAS system, which is also known as the 'Official Assessment System' (OAS), is different from the post 'Self-Assessment System', simply called 'SAS', which is currently used for taxation in the country, and executed electronically and solely by the taxpayers themselves, whereas the pre-SAS system is executed manually by the taxpayer and the Inland Revenue Board of Malaysia (IRBM). Thus, taxpayers are expected to be knowledgeable regarding the tax system in order to comply with the tax system since the latest Malaysian tax system (SAS) requires taxpayers' decision making. However, taxpayers in Malaysia, especially the educated, are indifferent and unresponsive to the tax compliance 
system (Soliha \& Nadiah, 2020). Even the professionals in the country are unconcerned of the tax compliance system and thereby escape from paying their taxes to the government. Healthy tax compliance particularly important since it could reduce the tax gap, increases the national revenue, and stabilizes the national economy.

Therefore, this study wishes to find answers for the following research question

- Does tax knowledge motivate tax compliance in Malaysia?

\section{Literature Review}

\subsection{Tax Compliance}

Tax compliance is defined as an accurate and truthful tax reporting with precise calculation of liability, payment of the amount before due and well-timed filing of return (Kiow et al., 2017; Walsh, 2012). On the other hand, non-tax compliance could reduce the national revenue and decreases national solidity by advancing deception. Hence, it is substantial for the tax authorities to recognize the incentive of taxpayers' non-compliance. Tax non-compliance is characterized as manipulation, adulteration and crude form by Kasipillai and Shanmugam (1997). The crude form of non-compliances indicates underreporting the actual income and overstating expenditures. As for manipulation of accounts, it was mostly found in the corporate sector where documents are duplicated or mock to decrease the accruals. Adulteration was explained as money laundering outside the country that was frequently found in the corporate sector. However, most of the individual tax compliance issues categorized as the crude form of non-compliance by under-reporting the income and overstating the expenses. Since this study focuses on individual taxpayers' tax compliance behaviour, the variables studied mostly related to the crude form of non-compliance.

\subsection{Tax Knowledge}

When considering the attitudes of individual taxpayers, the tax law knowledge is essential. (Manual \& Xin, 2016; Wassermann \& Marina, 2020) and tax knowledge forms a significant positive association with tax compliance level (Mukhlis et al., 2015). Despite the fact that limited research focusing on tax knowledge, it has been found that education do shows a vital role since the application of the Self-Assessment System that required personal tax knowledge (Kasipillai et al., 2003; Harijito, 2005). Among the activities in the Self-Assessment System, filing tax returns before due and accurate computation of tax liabilities need a certain level of tax knowledge (Marziana et al., 2010; Kirchler et al., 2008; Lymer \& Oats, 2009). Kasipillai and Shanmugam (1997) mention that when one has tax knowledge, the compliance level with the tax system could be stimulated. Even though the aspects of individual attitudes such as tax ethics and the equality of the tax system may lead to the tax evasion, it should also be noted that the general tax knowledge do has a close association with taxpayers' compliance level (Singh, 2003).

On the other hand, Kasipillai et al. (2013), in their findings indicates that tax knowledge has a negative association with tax compliance behavior. The said study found that the better the tax knowledge, the more likely the taxpayers could identify the loopholes in the tax system and regulations, which resulted tax non-compliance. Additionally, Soliha \& Nadiah (2020) argued that tax knowledge has no direct significant relationship on individual taxpayer's tax compliance behavior.

\subsection{Age}

Perumal (2008) discovered that elderly taxpayers comply with the tax system more than young aged taxpayers. A similar finding was noted by Mason and Calvin (1978), Serwinek (1992), and Wenzel (2001a). The reason for the verdict is clearly explained by Wenzel (2001a) in that aged people were more aware of and had experienced the penalties of non-compliance. While the researcher explains the significant difference between age groups towards tax compliance behavior, Hai and See (2011) found a negative association between age and tax compliance behavior. Though, the study did not disclose the significant difference between the age group and did not mention the degree of compliance by age group. Another study had been carried out by Vogel (1974), Friedland et al. (1978), Mason and Calvin (1978), Slemrod and Sorum (1984), and Feinstein (1991) which indicate that age has a positive association with tax compliance behavior that contradict the results found by Hai and See (2011). In contrast to all the results discussed above, Ross and McGee (2011) noted that there are no significant relationship exists between age groups towards tax compliance behavior in Malaysia. Age is not an influential factor to determine tax compliance behavior since age is not only the factor that influences tax compliance (Kasipillai et al., 2003). Consequently, prior literature has shown mixed findings for the relationship between age and tax compliance behavior. Thus, the mix conclusion in the literature failed to derive a solid answer for tax compliance behavior and its relationship with age.

\subsection{Gender}

Earlier studies also showed varied results regarding gender effect toward compliance behavior. According to Title 
(1980), females are more responsible than males in complying with the tax system. Kasipillai (2004), in a study about attitude, found that gender greatly influences tax compliance behavior in Malaysia. Similarly, Ross and McGee (2011) found that women in Malaysia do not hesitate to comply with the tax system. But the statistical output shows an insignificant difference between gender groups. Though, Kaplan, Pany et al. (2009) argued that females have a higher intention to perform under-reporting which leads to a reluctance to comply with the tax system. A similar argument but otherwise, Friedland et al. (1978) and Kirchler and Maciejousky (2001), clarify that men are more ethical than women. On the other hand, Mason and Calvin (1978), Spicer and Becker, (1980), Young, (1994), Wenzel, (2002), and Hassldine and Hite, (2003) have found that female comply better than males and they standpoint were against tax non-compliance. Whilst other researchers indicate a significant difference between the gender groups among taxpayers, Hai and See (2011) found a negative association between gender and tax compliance, particularly among sole preparatory businesspersons. Additionally, Kasipillai and Jabbar (2006) noted that there was an equal non-compliance behavior. Thus, in summary, there are no typical finding on the association between gender and tax compliance behavior.

\subsection{Income Level}

Earning position is an indirect factor that influences tax compliance (Chan et al., 2000). According to Ross and McGee (2011), a low-income level leads to money shortages, which in turn leads to noncompliance with the tax system. Further, it explains that high-income earners are not involved in tax non-compliance. Similar findings were obtained by Alm et al. (1992) where there are positive association between income group and tax compliance behavior. In other words, higher-income earners will respect the tax system and the lower-income earners will not. This is supported by Feinstein (1991) and Houston and Tran (2001) who noted that tax non-compliance was recorded mostly among the low-income earners but the difference between income groups found was insignificant. In contrast, Crane and Nourzad (1990) and Young (1994) found a negative association between income level and compliance behavior. According to their research, higher-income earners tend to evade tax more than lower-income earners. Ritsema et al. (2003) had quite different findings in that middle-income earners were found to comply with the tax system more than other income groups. Hence, there is no standard finding on the relationship between income level and tax compliance behavior.

\subsection{Education Level}

Previous empirical studies revealed that higher education level influences the tax compliance among taxpayers since the education gained would facilitate the respect of law and regulations (Ross \& McGee, 2011). To support this fact, Obid (1994) and Lee and Carley (2009) found a positive association between education level and tax compliance behavior. The greatest level of knowledge that taxpayers have directly influenced the chances to comply with the tax system. As education allows the taxpayers to understand the responsibilities and obligations that he/she has towards the country and the significance of the tax revenue for national development of a country (Mohani, 2001). In contrast, other studies have noted a negative relationship between education level and compliance behavior (Dubin \& Wilde, 1998). A higher education level enables and individual to find loopholes to escape from compliance (Ritsema et al., 2003). Apart from arguments found in the literature, those confirm the positive and negative association education level has towards tax compliance behavior and no significant differences between these two variables (Soliha \& Nadiah, 2020). The education level has been considered an important factor since researchers believe that education will assist an individual to understand the obligations, he/she has towards the nation. In the same argument, Ross and McGee (2011) also mention that misusing the tax system is possible when an individual earns higher-level education. Therefore, in summary, mix finding on the relationship between gender and tax compliance behavior does not allow to derive to a standard conclusion.

\subsection{Deterrence Theory}

This theory focuses on incentives profit maximization with minimum cost using the knowledge an individual gained (Brooks, 2001). A sensible taxpayer computes the risks and returns of tax evasion (Olaoye, 2017 and Walsh, 2012). If the returns outweigh the risks (probability to be penalized for non-compliance) then most likely the taxpayers decided to do tax evasion. Increasing the chances of getting caught increases the cost of evasion. Increasing the level of deterrence improves in compliance but it is often an expensive measure for the tax authorities. Therefore, the deterrence-based theory suggests the consequences of tax evasion have to be amplified by the tax authorities (Olaoye, 2017; Chukwadi, 2018).

\section{Methodology}

Applying the convenient sampling method, questionnaires are distributed through Google E-survey and printed 
hardcopies to the salaried taxpayers from multiple sectors across Malaysia using. According to the Department of Statistics Malaysia, there were around 14 Million employed individuals. However, this study follows the sample size based on the discussion by Krejce and Morgan (1970), which indicates that when the population is larger than seventy-five thousand, a sample size of three hundred and eighty-four is acceptable.

Section A of the questionnaire comprised of demographic information which include the respondents' educational background. Next is the Section B, which tested the level of tax knowledge by subdividing the variable into the following classifications: knowledge about taxpayer's rights and responsibilities (B1), Income from employment (B2), income from dividend (B3), income from interest (B4), personnel relief (B5), child relief (B6), rebates (B7), and knowledge about penalties and offenses (B8) (Loo, 2006 and Palil, 2010). This particular section attempt to obtained the respondent's awareness with three level of scales.

As for section $\mathrm{C}$, it attempts to acquire the tax compliance behavior. This section includes eleven different scenarios with regard to the tax compliance behavior. Ching (2013) and Gerxhani (2007) justified that dishonesty of respondents' answers could be reduced through indirect tax-related questions through scenario. This study developed scenario-based questions where respondents are asked to opt for one selection. Respondents need to answer "YES/ NO" for the scenario-based question visualizing similar situation as describe in that situation. Later, on the same scenario, respondents are required to select the likelihood (from low probability to high probability) that the respondent will embark on the same action illustrated in the scenario using 5 points Likert scale.

To measure the responds, 40\% was allocated for "YES/ NO" questions since the "YES/NO" type question does not require the respondents to spend much time to establish their decision. As for the probability responds, $60 \%$ was allocated in order to ensure the validity of the result. For instance, if a respondent answer "Yes" and " 5 " as the probability of carrying out the same action said in the scenario, he/ she will be scored $(1 * 0.4)+(1 * 0.6)=1$ score, which shows a high non-compliance.

\section{Results and Discussion}

There were 2,400 E-mails (with Google e-survey link) were distributed and 100 questionnaires were circulated by hand in Kuching and nearby suburbs. 647 emails were not delivered because of incomplete email address, non-active or the employee was not employed at that workplace anymore. From the 1,853 successfully delivered emails, 319 responses and 100 by-hand responses were received.

Reliability Test

Table 1. Cronbach's Alpha Reliability Test (Tax knowledge)

\begin{tabular}{cccc}
\hline & $\begin{array}{c}\text { Scale Mean if } \\
\text { Item Deleted }\end{array}$ & $\begin{array}{c}\text { Scale Variance } \\
\text { if Item Deleted }\end{array}$ & $\begin{array}{c}\text { Cronbach's } \\
\text { Alpha if Item } \\
\text { Deleted }\end{array}$ \\
\hline B1 & 7.8019 & 9.901 & .635 \\
B2 & 7.9785 & 9.447 & .618 \\
B3 & 8.2172 & 9.788 & .619 \\
B4 & 8.0621 & 9.312 & .602 \\
B5 & 7.8926 & 9.651 & .615 \\
B6 & 7.9570 & 10.137 & .639 \\
B7 & 8.0072 & 10.328 & .651 \\
B8 & 8.7375 & 10.170 & .622 \\
\hline
\end{tabular}

Table 2. Cronbach's Alpha Reliability Test (Tax compliance)

\begin{tabular}{cccc}
\hline & $\begin{array}{c}\text { Scale Mean if } \\
\text { Item Deleted }\end{array}$ & $\begin{array}{c}\text { Scale Variance if } \\
\text { Item Deleted }\end{array}$ & $\begin{array}{c}\text { Cronbach's } \\
\text { Alpha if Item } \\
\text { Deleted }\end{array}$ \\
\hline PAUD & 13.9928 & 15.572 & .944
\end{tabular}




\begin{tabular}{clll} 
GOVS & 14.0143 & 15.182 & .939 \\
EQFR & 13.9570 & 15.041 & .938 \\
PRAT & 13.9905 & 15.005 & .938 \\
FPOS & 13.9785 & 14.930 & .937 \\
GOVP & 13.9809 & 14.971 & .937 \\
RFGRP & 13.9761 & 14.995 & .938 \\
RLLHDN & 13.9427 & 15.327 & .942 \\
POLI & 14.1026 & 15.657 & .943 \\
CULTI & 14.0477 & 16.696 & .955 \\
RLG & 14.2172 & 16.812 & .951 \\
\hline
\end{tabular}

Table 3. Normality Test - Demographic variables

\begin{tabular}{lllll}
\hline & Gender & Age & Education & Income \\
\hline $\mathrm{N}$ & 419 & 419 & 419 & 419 \\
Mean & 1.57 & 2.43 & 3.51 & 4.41 \\
Std. Deviation & .496 & .942 & .696 & 1.410 \\
Skewness & -.266 & .163 & -.478 & .350 \\
Kurtosis & -1.939 & -.859 & 2.118 & -.359 \\
\hline
\end{tabular}

A reliability test is conducted in order to measure whether the multi scales are internal by consistency and stability, and also to measure to what extent the questionnaire is biased (Hong, 2005). According to Hair et al., (2006), an alpha value of more than 0.700 is sufficient to proceed with data analysis, since the alpha highlights the reliability and validity of the data. However, an alpha value of 0.600 also acceptable when there are several variables, being tested. A further date is normally distributed since the Skewness and Kurtosis are in the range of -1 to +1 and -3 to +3 respectively (Refer to Table 3). Tables 1 and 2 show the reliability test which indicates that the instrument used is reliable.

\section{Knowledgeable Taxpayers}

Table 4. Multiple comparisons - Age

\begin{tabular}{|c|c|c|c|c|c|}
\hline \multicolumn{3}{|c|}{ Dependent Variable } & \multirow{2}{*}{$\begin{array}{c}\begin{array}{c}\text { Mean } \\
\text { Difference } \\
(\mathbf{I}-\mathbf{J})\end{array} \\
-.16222\end{array}$} & \multirow{2}{*}{$\begin{array}{c}\begin{array}{c}\text { Std. } \\
\text { Error }\end{array} \\
.06143\end{array}$} & \multirow{2}{*}{$\begin{array}{c}\text { Sig. } \\
.074\end{array}$} \\
\hline \multirow[t]{12}{*}{ TK } & $20-30$ & $31-40$ & & & \\
\hline & & $41-50$ & $-.29158^{*}$ & .06473 & .000 \\
\hline & & 51 and above & -.13949 & .07406 & .316 \\
\hline & $31-40$ & $20-30$ & .16222 & .06143 & .074 \\
\hline & & $41-50$ & -.12936 & .05141 & .098 \\
\hline & & 51 and above & .02273 & .06275 & .988 \\
\hline & $41-50$ & $20-30$ & $.29158^{*}$ & .06473 & .000 \\
\hline & & $31-40$ & .12936 & .05141 & .098 \\
\hline & & 51 and above & .15208 & .06599 & .152 \\
\hline & 51 and & $20-30$ & .13949 & .07406 & .316 \\
\hline & above & $31-40$ & -.02273 & .06275 & .988 \\
\hline & & $41-50$ & -.15208 & .06599 & .152 \\
\hline
\end{tabular}


Table 5. T-test - Gender

\begin{tabular}{llllll}
\hline & & N & Mean & $\begin{array}{l}\text { Std. } \\
\text { Deviation }\end{array}$ & $\begin{array}{l}\text { Std. Error } \\
\text { Mean }\end{array}$ \\
\hline TK & Male & 182 & 1.1875 & .44477 & .03297 \\
& Female & 237 & 1.1292 & .43115 & .02801 \\
\hline
\end{tabular}

Table 6. Multiple comparisons- Income level

\begin{tabular}{|c|c|c|c|c|}
\hline \multicolumn{2}{|c|}{ Dependent Variable } & \multirow{2}{*}{$\begin{array}{c}\begin{array}{c}\text { Mean } \\
\text { Difference } \\
\text { (I-J) }\end{array} \\
.02500\end{array}$} & \multirow{2}{*}{$\begin{array}{c}\begin{array}{c}\text { Std. } \\
\text { Error }\end{array} \\
.22552\end{array}$} & \multirow{2}{*}{$\begin{array}{l}\text { Sig. } \\
1.000\end{array}$} \\
\hline TK $<1,000$ & $1,001-3,000$ & & & \\
\hline & $3,001-5,000$ & -.18684 & .20038 & .990 \\
\hline & $5,001-7,000$ & -.11364 & .19897 & .999 \\
\hline & $7001-9,000$ & -.16111 & .20066 & .996 \\
\hline & $9,001-11,000$ & -.28846 & .21326 & .934 \\
\hline & $>11,000$ & -.18527 & .20384 & .991 \\
\hline
\end{tabular}

Table 7. Multiple comparisons- Education level

\begin{tabular}{|c|c|c|c|c|c|}
\hline \multicolumn{2}{|c|}{ Dependent Variable } & & \multirow{2}{*}{$\begin{array}{c}\begin{array}{c}\text { Mean } \\
\text { Difference } \\
\text { (I-J) }\end{array} \\
-.17045\end{array}$} & \multirow{2}{*}{$\begin{array}{c}\begin{array}{c}\text { Std. } \\
\text { Error }\end{array} \\
.17045\end{array}$} & \multirow{2}{*}{$\begin{array}{l}\text { Sig. } \\
.801\end{array}$} \\
\hline \multirow[t]{12}{*}{ TK } & SPM/STPM & Certificate/Diploma & & & \\
\hline & & Degree/Professional & $-.41667^{*}$ & .14575 & .044 \\
\hline & & Master/PhD & $-.46154^{*}$ & .15052 & .025 \\
\hline & Certificate/Diploma & SPM/STPM & .17045 & .17045 & .801 \\
\hline & & Degree/Professional & -.24621 & .09518 & .084 \\
\hline & & Master/PhD & $-.29108^{*}$ & .10234 & .046 \\
\hline & Degree/Professional & SPM/STPM & $.41667^{*}$ & .14575 & .044 \\
\hline & & Certificate/Diploma & .24621 & .09518 & .084 \\
\hline & & Master/PhD & -.04487 & .05161 & .860 \\
\hline & Master/PhD & SPM/STPM & $.46154^{*}$ & .15052 & .025 \\
\hline & & Certificate/Diploma & $.29108^{*}$ & .10234 & .046 \\
\hline & & Degree/Professional & .04487 & .05161 & .860 \\
\hline
\end{tabular}

According to Table 5, males (mean=1.19) have higher tax knowledge than females. There is a statistical difference between SPM/STPM taxpayers and Degree/Professional Taxpayers as well as Master level taxpayers with significance levels of .044 and .025 respectively (Refer to table 7). At the same time, there is a significant difference between Master and Certificate level taxpayers in which Master/PhD level taxpayers have more tax knowledge than Certificate level taxpayers. Degree/ Professional or Master/PhD level taxpayers also have significantly higher tax knowledge compared with SPM/STPM or Certificate level taxpayers. The multiple comparison table shows the mean difference of each income group pertaining to tax knowledge. The mean difference between income earners RM 3,001 - 5,000 was 0.21. The mean differences between RM 9,001- 11,000 and income less than RM 1,000 as well as RM 1,001- 3,000 were 0.29 and 0.31 respectively. Furthermore, the mean difference between income groups more than RM 11,000, and RM 1,001 - 3,000 was 0.21. Earners of income between RM 9,001- 11,000 have higher tax knowledge than all other groups. 


\section{Better Taxpayers}

Table 8. T-test - Gender

\begin{tabular}{lllcr}
\hline Age & & N & Mean & Std. Deviation \\
\hline TCOM & Male & 182 & 17.3484 & 2.76325 \\
& Female & 237 & 17.0414 & 2.28155 \\
\hline
\end{tabular}

Table 9. Independent samples test

\begin{tabular}{lccccc}
\hline & \multicolumn{2}{c}{ Levene's Test } & \multicolumn{4}{c}{ t-test for Equality of Means } \\
\cline { 2 - 6 } & F & Sig. & t & df & Sig. (2-tailed) \\
\hline $\begin{array}{l}\text { Equal variances } \\
\text { assumed }\end{array}$ & 3.2 & 0.074 & 1.245 & 417 & 0.214 \\
$\begin{array}{l}\text { Equal variances not } \\
\text { assumed }\end{array}$ & & & 1.214 & 347.153 & 0.225 \\
\hline
\end{tabular}

According to the T-test results between gender and tax compliance behaviour, it clearly shows that female taxpayers have a lower compliance level than male taxpayers do (Refer Table 8). The average compliance among males is 17.35, which is higher than females. Based on the independent sample t-test output, the significance level under equal variance not assumed is above $1 \%(\mathrm{Sig}=0.225)$ which indicates that there is no significant difference between males and females in terms of tax compliance behaviour (Refer to Table 9)

Table 10. Descriptive- Age

\begin{tabular}{llrcrc}
\hline & & & & \multicolumn{1}{c}{ Std. } \\
TCOM & $20-30$ & 69 & 17.0478 & 2.63252 & .31692 \\
& & 165 & 17.1982 & 2.53878 & .19764 \\
& $31-40$ & 120 & 17.3783 & 2.50214 & .22841 \\
& $41-50$ & 65 & 16.8738 & 2.28735 & .28371 \\
& 51 and above & 419 & 17.1747 & 2.50370 & .12231 \\
\hline & Total & & & & \\
\hline
\end{tabular}

Table 11. ANOVA- Age

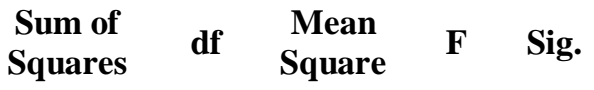

\begin{tabular}{llrrrrr}
\hline \multirow{2}{*}{ TCOM } & Between Groups & 12.061 & 3 & 4.02 & 0.64 & 0.59 \\
& Within Groups & 2608.171 & 415 & 6.285 & & \\
& Total & 2620.232 & 418 & & & \\
\hline
\end{tabular}

The ANOVA multiple comparison output and descriptive table reveal that taxpayers who are 41-50 years old (Refer to Table 10) tend to comply with the tax system more than the other age groups (Mean=17.37). Moreover, the significance level between the age groups is .590 which is very higher than 0.005 . Therefore, no difference exists between age groups in terms of tax compliance behavior (Refer to Table 11). 


\section{Education Background}

Table 12. Descriptive- Education level

\begin{tabular}{llrrr}
\hline & N & Mean & $\begin{array}{c}\text { Std. } \\
\text { Deviation }\end{array}$ \\
\hline \multirow{4}{*}{ TCOM } & SPM/STPM & 9 & 16.5111 & 2.11922 \\
& Certificate/Diploma & 22 & 17.4091 & 1.83353 \\
& Degree/Professional & 297 & 17.2404 & 2.48186 \\
& Master/PhD & 91 & 16.9692 & 2.74905 \\
& Total & 419 & 17.1747 & 2.5037 \\
\hline
\end{tabular}

Table 13. ANOVA - Education level

\begin{tabular}{llrrrrr}
\hline & $\begin{array}{c}\text { Sum of } \\
\text { Squares }\end{array}$ & df & $\begin{array}{c}\text { Mean } \\
\text { Square }\end{array}$ & F & Sig. \\
\hline \multirow{2}{*}{ TCOM } & Between Groups & 10.296 & 3 & 3.432 & 0.546 & 0.651 \\
& Within Groups & 2609.936 & 415 & 6.289 & & \\
& Total & 2620.232 & 418 & & & \\
\hline
\end{tabular}

According to the one-way ANOVA descriptive output, taxpayers with certificate/ Diploma level show a higher average in tax compliance with a means of 17.41 (Refer to Table 12). The value of $\mathrm{F}=546$ and an insignificance difference between groups $(\mathrm{p}=.651)$ indicates that there are no significant differences between the means of the education levels (Refer to Table 13).

Income Level

Table 14. Descriptive- Income level

\begin{tabular}{llrrrr}
\hline & N & Mean & $\begin{array}{c}\text { Std. } \\
\text { Deviation }\end{array}$ & $\begin{array}{c}\text { Std. } \\
\text { Error }\end{array}$ \\
\hline$<1,000$ & 5 & 17.36 & 2.96108 & 1.32424 \\
$1,001-3,000$ & 15 & 16.7867 & 2.24177 & 0.57882 \\
$3,001-5,000$ & 95 & 16.5105 & 2.13773 & 0.21933 \\
& $5,001-7,000$ & 132 & 17.8811 & 2.65022 & 0.23067 \\
& $7,001-9,000$ & 90 & 17.0844 & 2.09053 & 0.22036 \\
TCOM & $9,001-11,000$ & 26 & 17.6615 & 2.99694 & 0.58775 \\
& $>11,000 \quad$ & 56 & 16.6429 & 2.75911 & 0.3687 \\
& Total $\quad 419$ & 17.1747 & 2.5037 & 0.12231 \\
& Model Fixed $\quad$ Effects & & & 2.45706 & 0.12004 \\
\multicolumn{2}{l}{ Random Effects } & & & & 0.28193 \\
\hline
\end{tabular}

Table 15. ANOVA- Income Level

\begin{tabular}{llrrrrr}
\hline & & $\begin{array}{c}\text { Sum of } \\
\text { Squares }\end{array}$ & df & $\begin{array}{c}\text { Mean } \\
\text { Square }\end{array}$ & F & Sig. \\
\hline \multirow{2}{*}{ TCOM } & Between Groups & 132.933 & 6 & 22.156 & 3.67 & 0.001 \\
& Within Groups & 2487.298 & 412 & 6.037 & & \\
& Total & 2620.232 & 418 & & & \\
\hline
\end{tabular}


The descriptive table retrieved from one-way ANOVA reveals that the income group RM 5,001-7,000 has a higher mean (17.89) than the other income groups (Refer to Table 14). The ANOVA table shows that there is a significant difference between income groups in the tax compliance level ( $\mathrm{Sig}=.001, \mathrm{p}<0.05, \mathrm{~F}=3.67)$. The output table also reveals that the significance level is lower than $0.05(\mathrm{~F}=3.67, \mathrm{Sig}=0.001, \mathrm{p}<0.05)$. Therefore, there is a difference in income levels in terms of tax compliance behavior (Refer to Table 15).

According to the T-test results between gender and tax compliance behaviour, it clearly shows that female taxpayers have lower tax compliance than male taxpayers do. The independent sample t-test shows there is no difference ( $\mathrm{Sig}=0.074, \mathrm{p}>0.05$ ) between males and females in tax compliance behaviour. Kasipillai (2004) who expressed that gender greatly influences the tax compliance behaviour in Malaysia. In contrast, Vogel (1974), Friedland et al. (1978), Mason and Calvin (1978), Title (1980), Grasmick et al. (1984), Kinsey and Grasmick (1993), Hite (1997), Hasseldine and Hite (2003) and Mohamad et al. (2007) argued that females tend to comply more with the tax system than males. Ross and McGee (2011) who justified that women in Malaysia do not hesitate to fulfil the tax system. Hence, this research is not consistent with previous studies. Based on the literature review, a solid conclusion the gender has on tax compliance in Malaysia is not absolute. Richardson (2006), found that gender has no significant impact on compliance across 45 countries and he further stressed that the impact that gender has towards tax compliance behavior is inconsistent. Similar to this research, Ross and McGee (2011) finding also shown an insignificant difference between gender groups. The study explains Malaysian men and women are equally stand against tax evasion.

Taxpayers' who are 41-50 years old tend to comply with the tax system more than other age group taxpayers. However, no significant difference exists between age groups in terms of taxpayers' tax compliance behavior. This is because the population of Malaysia seems to be more homogenous in terms of demographic variables, especially age. Most of the respondents were fairly educated, those with Degree/Professional certificates contributing the highest percentage. But, taxpayers with certificate/ Diploma level taxpayers have a higher average in tax compliance. There is no significant difference between the means of education levels. Further, it also suggests that lower academic qualification taxpayers comply with the tax system more than taxpayers with higher education qualification.

However, the multiple comparison output reveals no differences between taxpayers with different educational backgrounds towards tax compliance with the tax system ( $p>0.05$ ). This finding contradicts that of Mohani (2001) who noted that the greater the level of knowledge that taxpayers have, the higher the chance of complying with the tax system. However, this study found that higher education background taxpayers have higher tax knowledge but not better complaints. In Malaysia, the highly educated people are found with a sophisticated approach, which encourages them to look for opportunities to reduce cash outflows.

The income group RM 5,001 to RM 7,000 has a higher mean (17.89) than the other income groups. There is a significant difference between the income groups in terms of tax compliance level $(\mathrm{p}<0.05)$. Thus, it shows that income level does matter in affecting tax compliance decisions in Malaysia. Taxpayers whose income level falls between RM 5,001-7,000 tend to better comply with the tax system than other income level groups. Ross and McGee (2011) explained that high-income earners are not much involved in tax noncompliance. This study found that not a very high income earners comply better, but middle-level income earners were noted to have the highest level of compliance. The reason of compliance with the tax system is that they worry about the psychological and mental punishment as cited by Kong (2014). Moreover, most of the respondents of this study fall under middle-income earners. A similar outcome was noted by Ritsema et al. (2003). This is because most of the respondents participated in this study falls under the middle-income group.

Table 16. Demographic characteristics of tax knowledgeable and better complaining taxpayers

\begin{tabular}{ccc}
\hline $\begin{array}{c}\text { Demographic } \\
\text { Factors }\end{array}$ & Tax Knowledge & Tax Compliance \\
\hline Gender & Male & Male \\
Age & $41-50$ & $41-50$ \\
Education Level & Master/Ph.D & Certificate/Diploma \\
Income Level & RM7,001-RM9,000 & RM5,001-RM7,000 \\
\hline
\end{tabular}


Table 17. Correlation between tax knowledge and tax compliance

\begin{tabular}{llll}
\hline & & TCOM & TK \\
\hline TCOM & Pearson Correlation & 1 & -.015 \\
& Sig. (2-tailed) & & .763 \\
TK & Pearson Correlation & -.015 & 1 \\
& Sig. (2-tailed) & .763 & \\
\end{tabular}

**. Correlation is significant at the 0.01 level (2-tailed)

The above-presented Table 16 compares the mean differences between tax knowledge and tax compliance level. The tax knowledge column presents who are the knowledgeable taxpayers and the tax compliance column presents who are the better complaining taxpayers. Taxpayers aged between 41-50 have a higher tax knowledge than taxpayers aged between 20-30 and this is confirmed with a 5\% significance level with a mean difference of 0.29 (Refer to table 4). According to the Pearson Correlation, the correlation between tax knowledge and tax compliance results in -.015 (p>0.01). Therefore, the hypothesis "H1: There is a significant relationship between tax knowledge and tax compliance" is rejected. Similar results were received by Lewis (1982) explains that tax knowledge correlates negatively with tax compliance behaviour. However, these results contradict many other research outcomes in those researchers found that positive correlation exists between tax knowledge and tax compliance behavior (Harris, 1989; Singh, 2003; Singh and Bhupalan, 2001; Mohamad Ali et al. 2007; Wassermann \& Marina, 2020). Malaysian thinking that it takes hard work to meet the basic needs and looking closely to find ways to control costs since tax knowledge has a negative association with tax compliance behavior in Malaysia. Finding loopholes in the tax system would benefit to avoid paying tax and this prioritized over their sense of obligation towards the country because the negative relationship means the lower the tax knowledgeable people higher complaining with the tax system. However, this conclusion cannot be solid since the relationship is insignificant. Further, the relationship can be also interpreted as taxpayers who possess higher tax knowledge are more likely to engage in tax avoidance. This conclusion is parallel with Obid (2004). Further, Fancheng (2014) supports with a statement that says an increase of tax knowledge increases tax non-compliance because people received good knowledge of tax thought that the chances of non-compliance being caught were small. The correlation output (Refer to Table 17) also support the evidence by showing that the association between tax knowledge and tax compliance level is weak, negative, and insignificant $(r=-.015$, sig=.763, $p>0.01)$.

\section{Conclusion}

A comprehensive analysis of this paper was carried out on individual taxpayers' tax compliance behaviour by examining the said relationship with tax knowledge. Following an extensive review of related literature and from the findings, the study concludes that an insignificant relationship exists between tax compliance behaviour and tax knowledge. An individual's tax knowledge impact was discussed through statistical findings. Interestingly, taxpayers with a higher level of tax knowledge was found as not a better taxpayer in Malaysia. Further, people use their knowledge to enjoy profit maximization, which supports Deterrence Theory.

However, this study has limitations that the measurement of an individual's compliance was based on the respondents' decision-making. Tax non-compliance is a sensitive area, wherein a respondent is anxious to give a true response to the question. Therefore, it would be suggested that in future study, designing a scenario-based question would help to evaluate their stand on the decision-making. Furthermore, this study tested tax knowledge as determinants to tax compliance behaviour through statistical analysis simply to determine the significance. It is recommended to analyse the reason why the said determinant did not determine the tax compliance behaviour. Therefore, deep analysis of qualitative data collection through unstructured interview would worth for future study.

The outcome of this study signifies the tax compliance literature specifically in explaining the relationship between tax knowledge and the level of tax compliance in Malaysia. Due to the inadequate available resources, the function of the Inland Revenue Board to identify the actual causes behind the tax non-compliance behaviour was limited. Issues related to tax evasion or tax non-compliance behaviour is the essential concerns for policymakers. Therefore, these findings will contribute to the policy makers, especially the tax authority, during policy planning, help the administration to develop stronger compliance risk treatment, and also to adopt the "Right from the Start" model. 


\section{Acknowledgements}

The authors wish to thank Ministry of Higher Education Malaysia for funding this research through the Fundamental Research Grant Scheme (F01/FRGS/2030/2020).

\section{References}

Ahangar, R., Bandpey, H., \& Rokny, H. (2011). An Investigation into the determinant of effective factors on tax evasion (Empirical study of Iran Tax Affairs Organisation). American Journal of Scientific Research, 5(2), 99-113.

Ahmed, A., \& Kedir, S. (2015). Tax Compliance and its Determinant: The Case of Jimma Zone, Ethiopia. International Journal of Research in Social Sciences, 6(2), 2-15.

Alabede, J., Ariffin, Z., \& Idris, K. (2011). Determinants of tax compliance behaviour: A proposed model for Nigeria. International Research Journal of Finance and Economics, 78(11), 5-11. https://doi.org/10.22164/isea.v5i1.54

Alm, J., \& Togler, B. (2006). Culture differences and tax morale in the United States and in Europe. Journal of Economic Psychology, 27(2), 224-246. https://doi.org/10.1016/j.joep.2005.09.002

Alm, J., Cherry, T. M., Jones, M., \& Mckee, M. (2010). Taxpayer Information Assistance Services and Tax Compliance Behavior. Journal of Economic Psychology, 31(4), 577-586. https://doi.org/10.1016/j.joep.2010.03.018

Behavioural Insights Team (BIT). (2012). Applying Behavioural Insights to Reduce Fraud, Error and Debt. UK, London: Cabinet Office.

Bhavish, S., Hema, S., \& Akshay, S. (2017). Tax Evasion and Economic Growth: Evidence from Mauritius. Journal of Public Economics, 3(7), 15-19.

Bobek, D., Roberts, L. H., \& Sweeney, C. F. (2007). Understanding attitudes toward progressive taxation. JSTOR, 8(2), 165-190. https://doi.org/10.1086/269417

Braithwaite, V. (2009). Defiance in Taxation and Governance: Resisting and Dismissing Authority in a Democracy. UK, Cheltenham: Edward Elgar.

Chan, W. C., Troutman, S. C., \& Bryan, D. (2000). An expanded model of taxpayer compliance: Empirical evidence from United States and Hong Kong. Journal of International Accounting, Auditing and Taxation, 9(2), 83-103. https://doi.org/10.1016/S1061-9518(00)00027-6

Ching, S. P. (2013). Determinants of tax non-compliance in Malaysia, Master Dissertation. Universiti Tunku Abdul Rahman, Malaysia.

Chong, K. R., \& Arunachalam, M. (2019). Determinants of Enforced Tax Compliance: Empirical Evidence from Malaysia. Advances in Taxation, 25(4), 147-172. https://doi.org/10.1108/S1058-749720180000025007

Chukwudi, D. (2017). Determinants of Tax Compliance Under the Self-Assessment System in Private Secondary Schools: Evidence from Delta North Senatorial Zone. Research Journal of Finance and Accounting, 9(7), $10-17$.

Coleman, C., \& Freeman, L. (1997). Cultural foundations of taxpayer attitudes to voluntary compliance. Australian Tax Forum, 13(3), 311-337.

Daily Express. (2017). Inland Revenue warns of syndicate out to cheat tax payers. National News. Retrieved from http://dailyexpress.com.my/news.cfm?NewsID=120656

Delaney, L., \& Harmon, C. (2009). Behavioural Economics and Taxation. Memo, Dublin: University College Dublin.

Fagbemi, T. O., Uadiale, O. M., \& Noah, A. O. (2010). The Ethics of Tax Evasion: Perceptual Evidence from Nigeria. European Journal of Social Sciences, 5(3), 360-371.

GAO. (2011). Tax Gap - Complexity and Taxpayer Compliance. US, Washington DC: Government Accountability Office, report GAO-11-747T.

Gërxhani, K. (2007). Explaining Gender Differences in Tax Evasion: The Case of Tirana, Albania. Feminist Economics, 13(2), 119-155. https://doi.org/10.1080/13545700601184856

Grasmick, H. G., Bursik, R. J., \& Cochran, J. K. (1991). Render Unto Caesar What Is Caesar's: Religiosity and Taxpayers' Inclinations to Cheat. The Sociological Quarterly, 32(2), 251-266. 
https://doi.org/10.1111/j.1533-8525.1991.tb00356.x

Grewal, I. (2018). Responsibilities of Individual Income Tax - 3E Accounting Malaysia. Retrieved April 5, 2019, from https://www.3ecpa.com.my/resources/malaysia-taxation/individual-income-tax/responsibilities-of-individual/

Gupta, R. (2015). Relational Impact of Tax Practitioners' Behaviour Interaction and Service Satisfaction: Evidence from New Zealand. E Journal of Tax Research, 13(1), 76-107.

Hanefah, M. (1996). An Evaluation of the Malaysian Tax Administrative System and Taxpayers Perceptions towards Assessment System, Tax Law Fairness and Tax Law Complexity, Doctoral Dissertation. Universiti Utara Malaysia, Malaysia.

Harjito, D. A., Omar, M. R., Arffin, A. N., \& Latiff, A. R. (2005). Tax Literacy Rate among tax payers: Evidence from Malaysia. Indonesian Journal of Accounting and Auditing, 9(1), 2-10.

Hasseldine, J., \& Hite, A. P. (2003). Framing, gender and tax compliance. Journal of Economic Psychology, 24(4), 517-533. https://doi.org/10.1016/S0167-4870(02)00209-X

Ho J. K., Loo E. C., \& Lim K. P. (2013). Perspective of non-taxpayers' perceptions on issues of ethics and equity in tax compliance. Malaysian Accounting Review, 5(2), 47-59.

Hong, T. J. (2005). Statistical Techniques in Business Research: A Practical Approach. Kuala Lumpur: Pearson Prentice Hall.

Kasipillai, J. (1999). Tax Implications on Derivative Financial Instruments: A Malaysian Perspective. The Asia-Pacific Journal of Taxation, 3(1), 20-30.

Kasipillai, J. (2002). Investigations and tax audit under the self-assessment system. The Chartered Secretary Malaysia, 16(22), 5-7.

Kasipillai, J. (2004). Malaysia: 2003 Year in Review. Tax Notes International, 33(1), 7-15.

Kasipillai, J., \& Baldry, J. (1998). What do Malaysian taxpayers know?. Malaysian Accountant, 2(7), 51-72.

Kasipillai, J., \& Shanmugam, M. (1995). Malaysia: Towards a 2020 Vision of Taxation. Asia Pacific Tax Bulletin, 1(12), 5-15.

Kasipillai, J., Aripin, N., \& Amran, N. (2013). The Influence of Education on Tax Avoidance and Tax Evasion. eJournal of Tax Research, 1(2), 64-65.

Keen, M., Kim, Y., \& Varsano, R. (2006). The "Flat Tax(es)": Principles and Evidence. International Monetary Fund, 6(18), 33-35.

Kelman, C. H. (2006). Interests, relationships, identities: three central issues for individuals and groups in negotiating their social environment. Annual Review of Psychology, 57(4), 1-26. https://doi.org/10.1146/annurev.psych.57.102904.190156

Kelman, H. C. (1958). Compliance, Identification, and Internalization: Three Processes of Attitude Change. Journal of Conflict Resolution, 2(1), 51-60. https://doi.org/10.1177/002200275800200106

Kiow, T. S., Salleh, M. F. M., \& Kassim, A. A. (2017). The Determinants of Individual Taxpayers' Tax Compliance Behaviour in Peninsular Malaysia. International Business and Accounting Research Journal, 1(1), $26-43$. https://doi.org/10.15294/ibarj.v1i1.4

Kirchler, E., Hoelzl, E., \& Wahl, I. (2008). Enforced versus voluntary tax compliance: The "slippery slope”, framework. Journal of Economic Psychology, 29(2), 210-225. https://doi.org/10.1016/j.joep.2007.05.004

Krejcie, R. V., \& Morgan, D. W. (1970). Determining sample size for research activities. The NEA Research Bulletin, 38(1), 99-100.

Loo, E. C. (2006). Tax knowledge, tax structure and compliance: A report on a quasi-experiment. New Zealand Journal of Taxation Law and Policy, 12(2), 117-140.

Loo, E. C., Evans, C., \& Mckerchar, M. A. (2010). Challenges in Understanding Compliance Behaviour of Taxpayers in Malaysia. Asian Journal of Business and Accounting, 3(2), 101-117.

Luttmer, F. E., \& Singhal, M. (2014). Tax Morale. Journal of Economic Perspectives, 28(4), $149-168$. https://doi.org/10.1257/jep.28.4.149 
Lymer, A., \& Oats, L. (2009). Taxation: Policy and Practice. Birmingham: Fiscal Publications.

Marziana, M., Ahmad, N., \& Deris, S. M. (2010). Perceptions of Taxpayers with Level of Compliance: A Comparison in the East Coast Region, Malaysia. Journal of Global Business and Economics, 1(1), 241-257.

McGee, R. W., \& Gelman, W. (2009). Opinions on the Ethics of Tax Evasion: A Comparative Study of the USA and Six Latin American Countries. Akron Tax Journal, 24(3), 6-7.

Modugu, K., \& Anyaduba, J. (2014). Impact of Tax Audit on Tax Compliance in Nigeria. International Journal of Business and Social Science, 5(9), 207-215.

Mukhlis, I., Utomo, H. S., \& Soesetio, Y. (2015). The Role of Taxation Education on Taxation Knowledge and Its Effect on Tax Fairness as well as Tax Compliance on Handicraft SMEs Sectors in Indonesia. International Journal of Financial Research, 6(4), 9-17. https://doi.org/10.5430/ijfr.v6n4p161

Murphy, K. (2004). The Role of Trust in Nurturing Compliance: A Study of Accused Tax Avoiders. Law and Human Behavior, 28(2), 187-209. https://doi.org/10.1023/B:LAHU.0000022322.94776.ca

National, N. (2017, October 25). LHDN reveals cheating syndicate using its name and logo. Retrieved September 18, 2018 , https://www.thesundaily.my/archive/lhdn-reveals-cheating-syndicate-using-its-name-and-logo-JTARCH495869

NEF. (2005). Behavioural Economics: Seven Principles for Policy-Makers. UK: New Economics Foundation.

Nokman, F. S. (2017, April 13). Exclusive: IRB 'cheated of billions'. Retrieved September 18, 2018, from https://www.nst.com.my/news/nation/2017/04/230018/exclusive-irb-cheated-billions

OECD. (2010). Understanding and Influencing Taxpayers' Compliance Behaviour. France, Paris: Organisation for Economic Cooperation and Development Forum on Tax Administration.

Oladipupo, A. O., \& Obazee, U. (2016). Tax Knowledge, Penalties and Tax Compliance in Small Medium Scale Enterprises in Nigeria. I Business, 8(1), 1-9. https://doi.org/10.4236/ib.2016.81001

Olaoye, C. O. (2017). Tax Information, Administration and Knowledge on TaxPayers' Compliance of Block Moulding Firms in Ekiti State. Journal of Finance and Accounting, 5(4), 131-146.

Palil, M. (2010). Tax Knowledge and Tax Compliance Determinants in Self-Assessment System in Malaysia, Doctoral dissertation. The University of Birmingham.

Palil, M. R., \& Mustapha, A. F. (2011). Determinants of tax compliance in Asia: A case of Malaysia. European Journal of Social Sciences, 24(1), 7-32.

Palil, M. R., Hamid, M. A., \& Hanafiah, M. H. (2013). Taxpayers Compliance Behavior: Economic Factor Approach. Jurnal Pengurusan, 38(13), 75-85. https://doi.org/10.17576/pengurusan-2013-38-07

Petee, T. A., Milner, T. F., \& Welch, M. R. (1994). Levels of Social Integration in Group Contexts and the Effects of Informal Sanction Threat on Deviance. Criminology, 32(1), 85-106. https://doi.org/10.1111/j.1745-9125.1994.tb01147.x

Piaw, C. Y. (2013). Mastering Research Statistics. McGraw Hill Education.

Pope, J., \& Jabbar, H. (2011). Tax Compliance Costs of Small and Medium Enterprises in Malaysia: Policy Implications, Doctoral dissertation. Curtin University, Malaysia.

Reeson, A., \& Dunstall, S. (2009). Behavioural Economics and Complex Decision-Making: Implications for the Australian Tax and Transfer System. CSIRO/CMIS Report No. 09/110.

Riahi, A. (2004). Relationship between tax compliance internationally and selected determinants of tax morale. Journal of International Accounting, Auditing and Taxation, 13(2), 135-143. https://doi.org/10.1016/j.intaccaudtax.2004.09.001

Richardson, G. (2008). The relationship between culture and tax evasion across countries: Additional evidence and extensions. Journal of International Accounting, Auditing and Taxation, 17(2), 67-78. https://doi.org/10.1016/j.intaccaudtax.2008.07.002

Ross, M. A., \& McGee, R. W. (2011). Attitudes toward Tax Evasion: A Demographic Study of Malaysia. Asian Journal of Law and Economics, 2(3), 6-14. https://doi.org/10.2202/2154-4611.1028

Sekaran, U. (2000). Research Methods for Business: A Skill Building Approach. New York: John Wiley and Sons. 
Sekaran, U. (2005). Cram 101 textbook outlines to accompany. Moorpark, Canada.

Shah, A. (2017). Tax dodgers may be put in credit blacklist. Retrieved September 18, 2018, from https://www.nst.com.my/news/exclusive/2017/11/304535/tax-dodgers-may-be-put-creditblacklist

Soliha, S., \& Nadiah, A. H. (2020). The Effect of Tax Knowledge, Compliance Cost, Complexity and Morale Towards Tax Compliance Among Self-Employed in Malaysia. Global Business and Management Research, 12(1), 1-16.

STA. (2005). Right from The Start - Research and Strategies. Sweden, Solna: Swedish Tax Agency.

The World Bank. (2018). Malaysia: Tax revenue. Retrieved September 14th 2019, from https://data.worldbank.org/indicator/GC.TAX.TOTL.GD.ZS

The World Bank. (2020). Malaysia Gross National Income | 2005-2020 Data | 2021-2022 Forecast | Historical. [online] Tradingeconomics.com. Retrieved 21 July 2020, from https://tradingeconomics.com/malaysia/gross-national-product\#: :text=In $\% 20$ the $\% 20$ long-term $\% 2 \mathrm{C} \% 20$ the $\% 2$ 0Malaysia\%20Gross\%20National\%20Income, in\%202022\%2C\%20according\%20to\%20our\%20econometric\%2 0models. $\% 203 \mathrm{Y}$

Torgler, B. (2003). Tax moral and institutions. Centre for Research in Economics, Management and the Arts, 14(2), 119-140. https://doi.org/10.1023/A:1023643622283

Torgler, B. (2004). Moral suasion: An alternative tax policy strategy? Evidence from a controlled field experiment in Switzerland. Economics of Governance, 5(3), 235-253. https://doi.org/10.1007/s10101-004-0077-7

Torgler, B. (2005). Tax morale and direct democracy. European Journal of Political economy, 21(2), 525-531.

Torgler, B. (2006). The importance of faith: Tax morale and religiosity. Journal of Economic Behaviour \& Organization, 61(1), 81-109. https://doi.org/10.1016/j.jebo.2004.10.007

Torgler, B. (2007). Tax Compliance and Tax Morale: A Theoretical and Empirical Analysis, Doctoral Dissertation. University of Zurich, Switzerland. https://doi.org/10.4337/9781847207203

Venkatesh, V., \& Davis, F. D. (2000). A Theoretical Extension of the Technology Acceptance Model: Four Longitudinal Field Studies. Management Science, 46(2), 186-204. https://doi.org/10.1287/mnsc.46.2.186.11926

Walsh, K. (2012). Understanding Taxpayer Behaviour - New Opportunities for Tax Administration. The Economic and Social Review, 43(3), 7-12.

Wassermann, M., \& Marina, B. (2020). Tax knowledge for the digital economy. Journal of Economics and Financial Sciences, 13(1), 1-11. https://doi.org/10.4102/jef.v13i1.461

Welch, M. R., Tittle, C. R., \& Petee, T. (1991). Religion and Deviance among Adult Catholics: A Test of the Moral Communities' Hypothesis. Journal for the Scientific Study of Religion, 30(2), 157-159. https://doi.org/10.2307/1387210

Welch, M. R., Xu, Y., \& Magro, P. (2005). But Everybody Does It: The Effects of Perceptions, Moral Pressures, And Informal Sanctions on Tax Cheating. Sociological Spectrum, 25(1), 21-52. https://doi.org/10.1080/027321790500103

Wenzel, M. (2001a). Misperceptions of Social Norms about Tax Compliance (1). Australian National University and Australian Tax Office Working Paper 7.

Wenzel, M. (2001b). Misperceptions of Social Norms about Tax Compliance (2). Australian National University and Australian Tax Office Working Paper 8.

Wenzel, M. (2005). Misperceptions of social norms about tax compliance: From theory to intervention. Journal of Economic Psychology, 26(6), 862-883. https://doi.org/10.1016/j.joep.2005.02.002

\section{Copyrights}

Copyright for this article is retained by the author(s), with first publication rights granted to the journal.

This is an open-access article distributed under the terms and conditions of the Creative Commons Attribution license (http://creativecommons.org/licenses/by/4.0/). 